\title{
Occupational Health \& Safety (OHS) management practices in micro- and small- sized enterprises: The case of the Portuguese waste management sector
}

\author{
Matilde A. Rodrigues ${ }^{\mathrm{a}, \mathrm{b}, \mathrm{c}}$, Ana Sáa ${ }^{\mathrm{a}}$, Donato Masi ${ }^{\mathrm{d}}$, Alexandra Oliveira ${ }^{\mathrm{e}, \mathrm{f}}$, Georgios
} Boustras $^{\mathrm{g}}$, Stavroula Leka ${ }^{\mathrm{h}, \mathrm{i}}$, Frank Guldenmund ${ }^{\mathrm{j}}$

\footnotetext{
${ }^{a}$ Health and Environment Research Centre, School of Health of the Polytechnic Institute of Porto, Porto, Portugal

b Algoritmi Centre, University of Minho, Guimarães, Portugal

${ }^{c}$ Center for Rehabilitation Research, School of Health of the Polytechnic Institute of Porto, Porto, Portugal

d Aston Business School, Aston University, Birmingham, B4 7ET, UK

${ }^{\mathrm{e}}$ LIACC/FEUP - Laboratory of Artificial Intelligence and Computer Science, Faculty of Engineering of Oporto University

${ }^{\mathrm{f}}$ Department of Biomathematics, School of Health of the Polytechnic Institute of Porto, Porto, Portugal ${ }^{g}$ CERIDES - Excellence in Innovation and Technology, European University Cyprus, 6 Diogenous Street, 2404 Nicosia, Cyprus

${ }^{\mathrm{h}}$ Cork University Business School, University College Cork, Ireland T12 K8AF Cork, Ireland

${ }^{i}$ Centre for Organizational Health and Development, School of Medicine, University of Nottingham, Nottingham NG8 1BB, UK

${ }^{j}$ Delft University of Technology, Safety Science Group, Jaffalaan 5, 2628 BX Delft, Netherlands
}

* Corresponding author at: Rua Dr. António Bernardino de Almeida, n 400, 4200-072 Porto, Portugal. E-mail address: mar@ess.ipp.pt (M.A. Rodrigues). 


\title{
Occupational health and safety management practices in micro- and small-sized enterprises: The case of the Portuguese waste management sector
}

\begin{abstract}
:
The waste management sector is dominated by micro and small-sized enterprises. Although it is possible to anticipate that they may face the same problems as other small firms, information about activities related to the prevention of occupational risks in this sector and how this influences Occupational Health \& Safety (OHS) performance is still limited. This study aims to address the issue, contributing to current literature about the protection of employees and the prevention of occupational risks in the waste management sector. The study was conducted at 66 enterprises in Portugal. Data about OHS management practices was collected through different sources, such as questionnaires applied to employers and analysis of documents and records available at the enterprise. A summative index that assesses seven OHS performance aspects was used to characterize the enterprises regarding their OHS performance level. The results showed that micro and small-sized waste management firms display several constraints with regard to OHS management. Several enterprises still do not have organized preventive services. Additionally, OSH policies or objectives, risk assessment, training and accident recording mechanisms were found to be non-existent in several cases. The time dedicated by employers to OHS issues and the support of external advisory services was also low for some firms. A positive and statistically significant association was found between these variables and the enterprises' OHS performance level. Future research will focus on designing an intervention to improve OHS in the waste management sector as a whole.
\end{abstract}

Keywords: Micro-sized enterprises; Occupational risks; OHS performance; Small-sized enterprises; Waste management sector

\section{INTRODUCTION}

Occupational Health and Safety (OHS) aims at improving the working conditions and the health of workers and it plays a pivotal role for societies, companies and individuals. In addition to the moral obligation of ensuring the protection of people in the workplace, an effective management of safety and health conditions can reduce costs related to accidents and diseases, such as medical care, sick leave and disability benefit (Tappura et al., 2015). Given the relevance of OHS, policy makers, researchers and practitioners have devoted important resources to understanding the factors that improve the effectiveness of OHS management practices. Previous studies have highlighted how OHS is the result of managerial, cultural and normative factors (EU-OSHA, 2010; Rosness et al., 2012), and they have studied OHS management practices in relation to other organizational features, such as company performance (Fernández-Muñiz et al., 2009) or company culture (Granerud and Rocha, 2011).

The abovementioned studies and other similar research have focused on different sectors, prioritizing ones with high OHS risks and more accidents such as construction or mining. These studies, however, rarely focus on the waste management sector, even though this sector is critical for several reasons. Firstly, workers in the waste management sector are at high risk of suffering an occupational accident or disease due to their exposure to a variety of risk factors, whether ergonomic, chemical, biological, mechanical and physical (Kuijer et al., 2010; Engkvist, 2010, Binion \& Gutberlet, 2012; Neitzel et al., 2013; Poole \& Basu, 2017; Zolnikov et al., 2018; Madsen et al., 2019). Secondly, these risks are exacerbated by a continuously changing working environment, limited 
human, economic and technological resources devoted OHS (see, for example, Micheli \& Cagno, 2010; Reinhold et al., 2015; Masi \& Cagno, 2015; Bonafede et al., 2016; Barbosa et al., 2019), and OHS policy designed solely by owners/managers (Hasle et al., 2012). Thirdly, the EU has been promoting a transition towards a more circular economy (European Parliament, 2017) that encourages the reduction, recycling and reuse of waste. Waste management enterprises play a pivotal role in this context.

In the light of the above considerations, this paper explores OHS management practices in the waste management sector and analyses the relationship between these practices and the corresponding results in terms of OHS performance.

The paper is structured as follows: Section 2 reviews the literature on OHS in the waste management sector and in small and medium-sized enterprises (SMEs); Section 3 summarizes the research methodology; Section 4 presents the results; Section 5 proposes a discussion of the results and Section 6 takes the conclusions.

\section{LITERATURE REVIEW}

\subsection{OHS in the waste management sector}

The waste management sector includes enterprises responsible for a wide range of operations related to the collection, treatment, disposal and recovery of residential, commercial and industrial waste. These enterprises are, in general, small in size (Engkvist, 2010; Eurostat, 2013): in 2010, almost 76\% of European enterprises operating in NACE division 38 (waste collection, treatment and disposal activities; materials recovery) were micro-sized firms and 17\% small-sized firms (Eurostat, 2013).

Greater environmental awareness and more stringent regulations in terms of waste management are increasing the number and importance of waste management enterprises. Portugal represents a significant example, since in 2014 a total of 805 waste management enterprises employed about 14,000 people and generated a turnover of roughly 1.5 billion euros, and the number of enterprises grew by 10\% between 2010 and 2014 (INE, 2014).

At the same time, epidemiological literature demonstrates that high accident rates are prevalent in the waste management sector. Among others, Engkvist (2010) found a high frequency of injuries and minor injuries at recycling centres and, similarly, Neitzel et al. (2013) found that employees reported a regular occurrence of accidents, injuries and pain related to ergonomic hazards.

Negative OHS performance is the result of several criticalities that characterize OHS management in the waste management sector. A first source of criticality depends on the risks that the workers face. The presence of waste generates chemical and biological risks. The use of hazardous machinery such as forklift trucks or other heavy machinery and heavy-duty vehicles produces significant physical risks (Neitzel et al., 2013). In addition, employees often perform intrinsically risky tasks such as the manual sorting of different materials for recycling, the manual handling of garbage bags and containers, and the dismantling of equipment and end-of-life vehicles. Summing up, the risk factors listed in the literature are ergonomic (e.g. repetitive motions, heavy manual handling and awkward working postures), physical (e.g. noise and vibrations), chemical (e.g. volatile organic compounds, polycyclic aromatic hydrocarbon and heavy metals), biological (components of dust of biological origin such as bacteria and fungi), and mechanical (e.g. use of cutting and drilling equipment, machines in circulation, work-at-height, etc.) (Engkvist, 2010, Binion \& Gutberlet, 2012; Neitzel et al., 2013; Poole \& Basu, 2017; Zolnikov et al., 2018; Madsen et al., 2019). Psychosocial risks may also be relevant: Engkvist (2010), for instance, found that employees could face aggression and conflicts and decide to work alone. 
A second source of criticality in terms of OHS is a consequence of the fact that the enterprises operating in the waste management sector are in general micro or small-sized enterprises. These enterprises often have fewer resources if compared to large enterprises and they do not prioritize OHS when allocating resources to the different business units (Champoux \& Brun, 2003). At micro enterprises, the owner/manager tends to take on several functions and responsibilities that include sales and purchasing, billing, planning, personnel, and general problem solving (Hasle et al., 2012). Given the complexity and demands of such a function, the owner/manager may neglect OHS, since his/her attention is focused on business and profitability. According to Masi et al. (2014), the owner/manager commitments in relation to OHS are one of the foremost factors that affect the success of programmes to prevent occupational injuries, illnesses and deaths. This situation generates more difficulties in effectively assessing and controlling risks (Sørensen et al., 2007; Boustras et al., 2015; Bonafede et al., 2016; Gopang et al. 2017; Rodrigues et al., 2017), and puts employees at a higher risk of occupational accidents and diseases (Fabiano et al., 2004; Sørensen et al., 2007).

A third source of criticality in terms of OHS originates from the difficulty in fulfilling legal requirements, such as missing risk assessments (Isik \& Atasoylu, 2017), failures related to the implementation of appropriate control measures (Kontogianni \& Moussiopoulos, 2017) and insufficient training (Engkvist, 2010; Kontogianni \& Moussiopoulos, 2017),

\subsection{OHS management practices}

The high risks that characterize the waste management sector, the prevalence of small-sized enterprises, and the difficulty in fulfilling OHS legal requirements suggest the need to investigate the most appropriate interventions for the improvement of OHS performances. An OHS intervention can be defined very simply as "an attempt to change how things are done in order to improve safety" (Robson et al., 2001). Interventions can occur at different levels; in general terms, it is possible to make a distinction between interventions occurring at workplace level and interventions occurring at community level. OHS interventions at workplace level include engineering solutions that decrease the probability of a worker engaging in at-risk behaviours, educating and training activities, and safety-related policies and procedures. OHS intervention at community level includes laws, regulations, standards and programmes put in place by governments, industries, professional bodies, and others.

OHS practitioners' activities are critical for the definition and implementation of OHS management in SMEs. Brun and Loiselle (2002) reviewed the literature on OHS practitioners' work, activities and work environment. They conclude that OHS practitioners' activities can be classified according to three dimensions of work, namely organizational, technical and human, and two activity levels, namely technical and organizational. The human dimension refers to the activities involving people within an organization; the technical dimension comprises those activities involving technical aspects, such as machines, equipment, raw and process materials; the organizational dimension consists of those activities which are characterized by the development of rules, policies and programmes. These activities may have an impact at strategic or operational level. OHS practitioners' activities are strategic when they include policies, work organization, allocation of resources and so forth. In contrast, operational activities include preventive maintenance, assessing risk, providing training, and so on. Other examples of OHS practitioners' activities associated with the two activity levels and the three dimensions of work are provided in Table 1. 
The purpose of this study is to analyse the relationship between OHS management practices and the corresponding results in terms of OHS performance. Given the exploratory nature of the study, the authors have decided to select five different OHS management practices covering the three dimensions of work, namely organizational, technical, and human, and the two activity levels, namely technical and organizational.

Most of the interventions covering the operational level and the technical dimension are legal requirements for SMEs. Therefore, the study analyses whether compliance with legal requirements influences OHS performance, and the first hypothesis has been formulated as follows:

H1. The higher the level of compliance with legal requirements, the higher the OHS performance level.

Regarding the strategic level and the human dimension, the study analyses whether fostering OHS among the top management influences OHS performance. Therefore, the second hypothesis has been formulated as follows.

H2. The greater the time dedicated by the employer to OHS issues, the higher the OHS performance level.

Regarding the operational level and the human dimension, the study analyses whether training workers influences OHS performance. Therefore, the third hypothesis has been formulated as follows.

H3: The higher the number of hours spent on OHS training, the higher the OHS performance level.

Regarding the operational level and the organizational dimension, the study analyses whether the number of visits by OHS external services influences OHS performance. Therefore, the fourth hypothesis has been formulated as follows.

H4: The greater the number of visits by OHS external services per year, the higher the OHS performance level.

Regarding the strategic level and the organizational dimension, the study analyses whether the existence of an OHS policy influences OHS performance. Therefore, the fifth hypothesis has been formulated as follows.

H5: The existence of OHS policies and objectives is related to higher levels of OHS performance

\section{METHODOLOGY}

\subsection{Sample}

A total of 143 Portuguese waste management enterprises that were part of the customer database of an insurance intermediary were contacted. Selection was limited to the insurance company database and to the following criteria: (1) size - micro (up to 10 employees) or small-sized (between 10 and 50 employees); (2) location - located in the 
north of the country; (3) activity - recycling activities. Of these, 66 agreed to participate in the study, representing 8\% of the entire sector in Portugal: $80.3 \%$ micro-sized enterprises and $19.7 \%$ small-sized enterprises. Regarding geographical location, $51.5 \%$ of the enterprises were in the district of Porto, 25.8\% in Aveiro, 18.2\% in Braga and 3\% in Viana do Castelo. The enterprises operated in one or more of the following activities: Scrap metals, Paper, Plastics \& Textiles (SPS\&T); Waste Electrical and Electronic Equipment (WEEE); End of Life Vehicles (ELV).

For all enterprises where the survey was conducted, a questionnaire was administered to the employers and employees. This paper describes only the results from employers. The 66 employers included in the study had a mean age of 46.7 years $( \pm 11.4$ years) and were mostly male $(73.3 \%)$. A large percentage of respondents had an education at high school level $(34.7 \%)$ or middle school level $(29.3 \%) .12 \%$ of the employers had a university degree.

\subsection{OHS management practices}

Data about the OHS management practices was collected from different sources as described below, such as the analysis of different documents and records related to OHS available at the enterprises (subsection 3.2.1) and questionnaires applied to the employers (subsection 3.2.2.).

\subsubsection{Analysis of documents and records}

Data was extracted from the following documents: (1) risk assessment reports; (2) training records; (3) accident analysis records; (4) contracts with external advisory services; (5) human resources records. Information was collected in situ by the research team, or requested directly from the employer via email or phone. Access to the different files was always provided by the owner. In some cases, documents and records were sent by email to the research team for analysis.

Quantitative information about training hours and occupational accidents were also extracted from the company records. Furthermore, using training reports, information was collected about the number of training hours on OHS matters in the last two years. The number of occupational accidents in the last two years was collected from accident records. Checks were carried out on whether there were any risk assessment reports; their content was analysed, but the results obtained fall outside the scope of this paper.

Human resources records were also analysed in order to collect information about the enterprises' activity, such as the starting year, the number of employees in the last two years, the employers' gender, as well as the number of hours worked. Information about preventive activities - in particular support from external consultancy companies, the year when this support started, the number of visits that external consults performed each year and the preventive activities included in the service provided - was extracted from contracts with external advisory services.

\subsubsection{Questionnaires}

A modified questionnaire obtained from the study by Boustras et al. (2015) was used for this research (Appendix A). The questionnaire was divided into two main parts. The first part asked for information about age, gender, education, age of enterprise, waste management activities carried out, number of workers (number of workers, number of managers and administrative support) and number of occupational accidents in the last two years.

The second part included several questions, of which only those relevant for this study scope will be described. Employers were asked about some mandatory prevention 
activities: provision of personal protective equipment (PPE), existence of an accident recording system, existence of a written risk assessment, provision of information about risks and training to workers and the presence of a health monitoring system. Example questions from this part of the questionnaire include 'I provide adequate Personal Protective Equipment to my employees' and 'I have an accident recording system', and these had to be answered as either Yes or No. The answers to these questions were used as a simple summative index to determine the level of compliance with legal requirements regarding these aspects. The level of compliance had a minimum score of 0 and a maximum of 6. Particular attention was given to the number of training hours provided to workers in the last year, where employers were requested to identify the number of training hours delivered to the workers on OHS matters. The existence of an OHS policy and/or objectives was also analysed ( $0=$ none; $1=$ only one of the two; $2=$ both). Employers were also asked to assess the time dedicated to health and safety issues on a 5-point scale ranging from "Very low" to "Very high".

\subsection{OHS performance level}

The enterprises under study were assessed by their level of OHS performance. The OHS performance measure was a summative index adapted from Boustras et al. (2015) (Appendix B). This index comprises seven performance aspects related to legal requirements, initiatives to improve OHS, PPE, general safety protection and OHS systems. The assessment scale varied according to the aspect under analysis; i.e., a 10point scale was applied to assess compliance with OHS legislation and regulations $(1=$ 'minimum'; 10 = 'maximum') and a 5-point scale for the remaining aspects ( $1=$ 'not at all' to $5=$ 'very much').

A summative score was obtained for the purpose of determining the level of OHS performance at each company, which ranged from 7 to 40. This assessment was performed by two experienced and independent OHS practitioners, who applied the scale in loco. Practitioners were recruited for this study because of their long history of experience with waste management firms, and due to the difficulty in including government health and safety inspectors as in Boustras et al. (2015). They accompanied the research team during the visits and contributed to observations and data collection. After the visits, they filled in a questionnaire regarding indicators of OHS performance at the enterprise. The index was then determined by the research team.

\subsection{Data analysis}

Descriptive statistics, i.e. percentages, mean and measures of dispersion, were used to summarize and describe the obtained results. Normality was tested through the application of the Shapiro-Wilks test. Once normality was violated, Spearman's coefficient was calculated to test correlations between OHS performance and independent variables: Injury frequency rates; Number of visits by OHS external services/year; OHS training (hours); Compliance with legal requirements; OHS objectives/policy; Time dedicated by employer to OHS issues.

Nested multiple regressions were used to determine the relative influence of the independent variables described above on OHS performance and to test the hypotheses. All models were fitted using least squared method.

A series of nested multiple regression analyses with least squared estimation method were conducted to test the hypotheses and to further assess the effect of the variables related to OHS management (described above) on the enterprises' OHS performance. All variables entered in the earlier steps were also included in the subsequent analysis. The variables referring to the amount of time invested by the employer in OHS issues, OHS 
training and the number of visits by external advisory services and OHS policies/objectives were considered as categorical variables being introduced as dummy variable with the lowest levels considered as the reference levels.

In the first step, control variables concerning the size and experience of the enterprise, such as the age of the enterprise, the total number of employees and the number of years carrying out OHS preventive activities were considered. Afterwards, in the second step, variables were included relating to OHS prevention activities, such as compliance with OHS legal requirements, the amount of time invested by the employer in OHS issues, OHS training and the number of visits by external advisory services. Finally, in the last step, a variable related to OHS policies/objectives was included.

The minimum sample size for larger model was determined as 66, considering $\alpha=$ 0.05 , a power of $80 \%$ and an effect size of $35 \%$. The assumptions of multiple linear regression for normality, linearity, homoscedasticity and lack of collinearity were checked with the common diagnostic tests (mainly by inspection of appropriate histograms, residual scatter plots, and normal probability plots), which confirmed that the models were properly specify.

We evaluated the goodness of fit of the model with the R-squared and adjusted Rsquare indexes which were also used to compare between the several fitted models. Moreover, it was considered, for each model, the F-statistic to check the usefulness of the model in the sense that fits better than the null model, i.e. with no independent variables.

Analysis were performed with Statistical Product and Service Solutions SPSS version 25 and $\mathrm{R}$ software version 3.6.0 .

\section{RESULTS}

\subsection{Characterization of enterprises in relation to OHS management practices and OHS performance}

Table 2 summarizes information about the enterprises' organizational variables, OHS preventive activities and OHS performance level. A total of 55 micro- and 12 small-sized firms were included in the study, which varied in the number of workers, with an average of almost 4 employees in micro-sized firms and 15 employees in small-sized firms. Although representing about $23 \%$ of the workforce on average, it is worth mentioning that $64.4 \%$ of the companies under study also employed female workers.

The surveyed firms have been operating, on average, for 14.51 years ( $\mathrm{sd}=11.31$ years). Of all the firms studied, $82.3 \%$ were dedicated exclusively to the management of a single category of waste, while the others managed two or more categories. According to collected data, out of 66 firms under study, 49 provided services in the field of SPS\&T, 12 provided services in WEEE and 23 operated ELV.

\section{\#Insert Table 2 about here\#}

OHS performance was determined through a summative index adapted from Boustras et al. (2015). The results showed that, on average, the firms under study had an OHS performance level of $31.01(\mathrm{sd}=5.00)$ points on a scale ranging between 7 and 40 . The injury-frequency rate was also determined as the number of accidents (all absences for 1 day or over) per million employee-hours worked; however, no significant correlation was found between the firm's OHS performance level and injury frequency rates $(r=0.013$; $\mathrm{p}>0.05$ ). The data showed that, on average, the injury-frequency rate was 80.03 (standard deviation $=93.32$ ).

The analysis of existing records/reports allowed us to see that at the enterprises that carried out OHS preventive activities, the employer had delegated this responsibility to 
external advisory services. In general, these providers were responsible for risk assessments, identifying control measures, accident investigation and analysis and, in some cases, OHS training, depending on the signed contract. On the other hand, those with no external prevention services support did not conduct any activity related to the protection and prevention of occupational risks. Data from Table 2 indicates this was the case at $10.8 \%$ of the firms. Additionally, it must be highlighted that the remaining enterprises also had problems with organizing preventive activities. In fact, although firms had been operating for many years $(\overline{\mathrm{x}}=14.51, \mathrm{SD}=11.31$ years $)$, preventive OHS services were only organized in recent years $(\overline{\mathrm{x}}=3.92, \mathrm{SD}=3.70$ years $)$.

When enterprises were identified to have external advisory services, the number of annual visits made by these enterprises to the customers was analysed. It was observed that in the last two years $30.5 \%$ of the firms under study had not received any visit from the external advisory provider, $28.8 \%$ had received one visit, $5.1 \%$ two and $35.6 \%$ three (Table 2). Data from Table 2 also denote the limited time spent by employer to deal with OHS issues. Only a small part of respondents considered the time dedicated to OHS activities as "Very high" $(1.3 \%)$ or "High" $(2.7 \%)$ and the majority indicated dedicating "Very low" (40.0\%) or "Low" $(25.3 \%)$ time.

Table 3 shows the outcomes of the analysed data for OHS management activities conducted at the companies. Analysis reveals that in almost all cases PPE and health monitoring were provided to employees $(97.3 \%)$. The majority of managers also indicated the existence of a written risk assessment; however, 10.8\% revealed they did not have one. Accident recording systems and OHS training were found to be missing in almost $30 \%$ of the cases. A detailed analysis about the training offered to the employees showed that in the last year $13.6 \%$ did not provide any training in OHS matters, although they had in the past. Additionally, on average, employees had about 1.5 hours/year of training on safety and health matters (Table 2). Nonetheless, the majority of employers noted that employees were provided with information about the risks that they are exposed to in the course of their daily tasks (91.9\%). Most respondents said that an OHS policy or objectives had not yet been defined.

\section{\#Insert Table 3 about here\#}

The time dedicated by employers to health and safety issues can be also a fundamental factor influencing OHS performance. However, most of the surveyed employers assessed this time as "very low" (40.0\%) or "low" (25.3). Only some of them considered the time spent as "moderate" ( $30.7 \%)$ or high ("high"=2.7\%; "very high"=1.3\%).

\subsection{Influence of OHS management practices on OHS performance}

In order to evaluate the strengths and the nature of the relationship between OHS performance and variables related to OHS management, various correlations were determined and are presented in Table 4. The correlations show that OHS performance is positively and significantly related to the existence of OHS objectives/policy $(r=0.399$, $\mathrm{p}<0.01)$, compliance with legal requirements in OHS $(\mathrm{r}=0.513, \mathrm{p}<0.01)$, time dedicated by employer to OHS issues $(r=0.411, \mathrm{p}<0.01)$, number of hours of OHS training $(r=0.337, p<0.01)$ and number of visits by external advisory services $(r=0.298$, $\mathrm{p}<0.01)$. Other interesting correlations were also found. For example, there were significant correlations between the time dedicated by employers to health and safety issues and the existence of OHS objectives/policy $(r=0.349, \mathrm{p}<0.01)$ and compliance with legal requirements $(\mathrm{r}=0.434, \mathrm{p}<0.01)$. 
To further assess the effect of the variables related to OHS management on the enterprises' OHS performance, a series of nested multiple regression analyses with least squared estimation method were conducted. The results of the three models tested are provided in Table 5.

Model 1 revealed a positive and significant effect of the number of years with OHS preventive activities on OHS performance $(\beta=0.519, \mathrm{p} \approx 0.002)$ but the effect of enterprise age and of the total number of employees was not detected ( $\beta=0.05$, n.s.; $\beta=$ 0.01 , n.s., respectively). The R-square was low: 0.214 meaning that $21.4 \%$ of the OHS performance can be explained by its relation with the independent variables (adjusted Rsquare 0.168$)$ and the model fits better than the null model $(\mathrm{F} \approx 4.627, \mathrm{p}<0.001)$.

Model 2 determines a positive and significant effect of a low amount of time dedicated to OHS issues $(\beta=3.245, \mathrm{p} \approx 0.02)$ as well as of a moderate amount of time $(\beta=2.959$, $\mathrm{p} \approx 0.034$ ) on OHS performance, when comparing both to a very low amount of time. It is worth noticing the positive though weak significant effect of the number of years with OHS preventive activities ( $(=0.419, \mathrm{p} \approx 0.064)$ and of the occurrence of 3 annual visits by external advisory services when compared to no visits $(\beta=2.387 ; \mathrm{p} \approx 0.091)$. The effects of the enterprise age, the number of employees, compliance with OHS legal requirements, high amount of time dedicated to OHS issues, very high amount of time dedicated to OHS issues, number of hours spent on OHS training and the remaining three profiles of annual visit by external advisory services on OHS performance were not detected $(\boldsymbol{\beta} \approx 0.076$, n.s.; $\boldsymbol{\beta} \approx 0.006$, n.s.; $\boldsymbol{\beta} \approx 0.811$, n.s.; $\boldsymbol{\beta} \approx 2.400$, n.s.; $\boldsymbol{\beta} \approx 1.916$, n.s.; $\boldsymbol{\beta} \approx 0.070$, n.s. ; $\boldsymbol{\beta} \approx 1.400$, n.s.; $\boldsymbol{\beta} \approx 0.712$, n.s., respectively). The R-square increased to 0.494 (adjusted R-square 0.349 ) and also this model fits better than the null model $(\mathrm{F} \approx 3.4 .12, \mathrm{p} \approx 0.001)$.

Model 3 added the OHS policies/objectives and revealed a positive and significant effect on OHS performance of a low amount of time dedicated to OHS issues ( $\beta=3.019$; $\mathrm{p} \approx 0.033$ ) when compared to a very low amount of time dedicated by the employer to OHS issues. Also, the occurrence of 3 annual visits by external advisory services when compared to no visits has a positive and significant effect on OHS performance $(B=$ $2.970 ; p \approx 0.049$ ). Similarly to model 2 , it is worth noticing the weak significant effect of the number of years with OHS preventive activities on OHS performance ( $\beta=0.417$; $\mathrm{p} \approx 0.068$ ). The effect of the enterprise age, the number of employees, compliance with OHS legal requirements, moderate amount of time dedicated to OHS issues, high amount of time dedicated to OHS issues, very high amount of time dedicated to OHS issues, number of hours spent on OHS training and the four profiles of annual visit by external advisory services on OHS performance were not detected $(\boldsymbol{\beta} \approx 0.089$, n.s.; $\boldsymbol{\beta} \approx 0.005$, n.s.; $\boldsymbol{\beta} \approx 0.498$, n.s.; $\boldsymbol{\beta} \approx 1.722$, n.s.; $\boldsymbol{\beta} \approx 0.801$, n.s.; $\boldsymbol{\beta} \approx 0.119$, n.s. ; $\boldsymbol{\beta} \approx 0.504$, n.s.; $\boldsymbol{\beta} \approx 1.412$, n.s.; $\boldsymbol{\beta} \approx 1.116$, n.s.; $\boldsymbol{\beta} \approx 1.298$, n.s.; $\boldsymbol{\beta} \approx 2.085$, n.s.; respectively). The $\mathrm{R}-$ square increased to a reasonable 0.514 (adjusted $\mathrm{R}$-square 0.344 ) and the model fits better than the null model $(\mathrm{F} \approx 3.018, \mathrm{p} \approx 0.003)$.

\section{\#Insert Table 5 here\#}

The results of the nested models supported the hypotheses about the number of years with OHS preventive activities, the amount of time dedicated to OHS issues (at least partially) and the occurrence of visits by external advisory (at least partially). 
H1. OHS performance has no statistically significant relationship with compliance with legal requirements after controlling for the age of the enterprise, the number of workers and the number of years with OHS. Hypothesis $\mathrm{H} 1$ is therefore not supported. It is noted that, as mentioned above, compliance with legal requirements as an individual variable without the impact of other variables has a positive and significant correlation with OHS performance.

H2. OHS performance has a positive and significant relationship with a low and moderate amount of time dedicated by the employer to OHS issues compared to a very low amount $(B=3.245, \mathrm{p}=0.02 ; \beta=2.9589, \mathrm{p}=0.034$ respectively). Hypothesis $\mathrm{H} 2$ has therefore been partially supported.

H3: OHS performance has no statistically significant relationship with the number of hours spent in OHS training after controlling for the age of enterprise, the number of workers and the number of years with OHS. Hypothesis H3 has not therefore been supported. It is noted that, as mentioned above, as an individual variable without the impact of other variables, OHS training has a positive and significant correlation with OHS performance.

H4: OHS performance has a positive but low significant relationship with three visits by external advisory services when comparing to enterprises which were not visited by external consultants for a year $(\beta=2.387, p=0.091)$. Hypothesis $H 4$ has therefore been partially supported.

H5: OHS performance has no statistically significant relationship with OHS policies/objectives after controlling for the age of enterprise, the number of workers and the number of years with OHS. Hypothesis H5 has not therefore been supported. It is noted that, as mentioned above, OHS policies/objectives as an individual variable without the impact of other variables has a positive and significant correlation with OHS performance.

\section{DISCUSSION}

The first result of the study is that OHS performance has no statistically significant relationship with compliance with legal requirements. However, at the same time, compliance with legal requirements as an individual variable has a positive and significant correlation with OHS performance. In line with these results, previous empirical studies on the effectiveness of workplace safety regulations are inconclusive. Among other authors, Shi (2009) reviewed several American econometric studies on the impact of the Occupational Safety and Health Act on OHS performance in the mining sector, concluding that the results are contradictory. The controversial results have been explained by the different methods of constructing variables (Shi, 2009) or by the fact that safety regulations can take years to become effective (Brandbury, 2006). The implication of this result for researchers is that new studies on the effect of regulation on OHS performance could benefit from the use of standardized variables, as well as from the creation of longitudinal databases that cover a timeframe of several years. The implication for practitioners is that simple compliance with regulation only represents the starting point for establishing a truly effective safety culture, in line with the prescription of other studies in the OHS literature (Cagno et al., 2014).

The second result of the study is that OHS performance has a positive and significant relationship with a low and a moderate amount of time dedicated by the employer to OHS 
issues compared to a very low amount. This result confirms previous studies demonstrating the relevance of employers' involvement for OHS performance in small enterprises (Champoux \& Brun, 2003; Hasle et al., 2012; Masi et al., 2014). The implication for researchers is that there is empirical evidence to extend the results of the abovementioned studies to the waste management sector, and further studies can investigate what interventions employers can implement to maximize the OHS performance of the firm in question. The implication for practitioners is that each intervention should leverage the role and importance of the employer to maximize the chances of success.

The third result of the study is that OHS performance has no statistically significant relationship with the number of hours of training on these matters, despite the observed positive and significant correlation with OHS performance as an individual variable. This result is not aligned with previous findings that have demonstrated the positive effect of training on OHS performance, and in particularly the positive effect of the average number of training hours in a working year on OHS performance (Micheli and Cagno, 2010; Hadjimanolis and Boustras, 2013; Cagno et al., 2014; Boustras et al., 2015; Hadjimanolis et al., 2015; Nordlof et al., 2015). The implication for researchers is that further studies are needed to understand why this result in the waste management sector is not aligned with previous findings in other sectors. A possible explanation is that employers at SMEs tend to consider mandatory training solely as a legal obligation and a waste of time, rather than as an opportunity for growth (Ma \& Yuan, 2009; Bonafede et al., 2016). Therefore, employers do not design the training interventions with the attention needed, and since these interventions are particularly complex (Colligan and Cohen, 2004), they become ineffective. The implication for practitioners is that they should devote particular care to the design of training interventions, and they should measure their effectiveness.

The fourth result of the study is that OHS performance has a positive but low significant relationship with the visits by external advisory services. Several researchers emphasized the importance external advisory services for OHS performance (see, for instance, Parejo-Moscoso et al., 2013). In line with these studies, Olsen and Hasle (2015) argued that external advisory services - called intermediaries - play an important role in disseminating national OHS programs to small businesses, but not much is known about the factors that influence their role. Our study seems to confirm a positive but ambiguous relationship in the waste management sector between visits by external advisory services and OHS performance. Therefore, the implication for researchers is that there is empirical evidence to extend the results of previous studies on the role of external services to the waste management sector. At the same time, the low significant relationship between visits by external advisory services and OHS performance suggests that more research is needed to understand the factors influencing this relationship. The implication for practitioners operating in the waste management sector is that they should carefully consider the allocation of resources to external consultants and other professional advisers to support OHS. Indeed, these advisory services represent an additional cost and their contribution to OHS performance may be limited.

The fifth result of the study is that OHS performance has no statistically significant relationship with OHS policies/objectives, despite the observed positive and significant correlation with OHS performance as an individual variable. This result is not aligned with previous findings that demonstrated the positive effect of the existence of a safety policy on OHS performance (see, for example, Boustras et al., 2015). The implication for researchers is that further studies are needed to understand why this result in the waste management sector is not aligned with previous findings in other sectors. Similarly to 
training, a possible explanation is that employers at SMEs tend to consider OHS policies/objectives a waste of time, rather than as an opportunity for growth (Bonafede et al., 2016). Therefore, the policies/objectives are often not tailored to the specific features of the enterprise and become ineffective. In this context, practitioners should be aware that the mere existence of policies/objectives does not guarantee a positive effect on OHS performance, but in a risky environment the policy should be carefully tailored to the specific features of the enterprise.

\section{CONCLUSION}

The findings of this research are important for both researchers and practitioners, raising issues related to OHS management practices in the waste management sector. It was found that some of the analysed enterprises do not carry out any actions at this level, nor have formally organized OHS services. When they do conduct activities related to the protection and prevention of occupational risks, external advisory enterprises were responsible for their implementation and monitoring in all cases; however, this support was found to be limited for several of the enterprises. The employers, which are the responsible for OHS prevention activities, were also found to dedicate a limited amount of time to these issues.

The results also showed that training on OHS given to the employees was limited and in several cases no training at all was provided. Some enterprises also failed to have accident recording mechanisms. These preventive actions are mandatory and can be critical for OHS performance.

The final model emphasized the hypotheses related to the time dedicated by the employer and the number of visits by external advisory services with regard to the influence on OHS performance level. However, the other OHS management practices analysed also have an important role in the enterprises' safety and health conditions and should be considered in interventions for the improvement of OHS performances in the waste management sector; however, more studies are still needed.

This study was a preliminary approach to a research work that intends to characterize OHS performance in the waste management sector. It is the authors' intention to further characterize this problem and, in the future, design an effective intervention programme for these enterprises.

\section{LIMITATIONS}

This study has some limitations, which have to be acknowledged and taken into account when interpreting the results. We strived to obtain reliable information for the different variables under study, using the documents and records available at the companies to extract it. However, it is important to recognize that some information may include some bias, such as the number of accidents, which may be underreported. This methodology could not be applied in all cases, and self-reporting measures were used instead.

OHS performance was also assessed using a self-reporting measure. Our findings could change if other indicators of OHS performance were used. Additionally, in our study, it was not possible to include government health and safety inspectors to assess OHS performance as in Boustras et al. (2015). Instead, we opted to include OHS practitioners who had experience with waste management firms.

\section{Acknowledgments}


Matilde A. Rodrigues has been supported by FCT - Fundação para a Ciência e Tecnologia (FCT) within the R\&D Units Project Scope: UIDB/00319/2020 and UIDB/05210/2020. Alexandra Oliveira has been supported by the European Regional Development Fund through the programme COMPETE by FCT (Portugal) in the scope of the project PEst-UID/CEC/ 00027/2015 and QVida+: Estimação Contínua de Qualidade de Vida para Auxílio Eficaz à Decisão Clínica, NORTE010247FEDER003446, supported by Norte Portugal Regional Operational Programme (NORTE 2020), under the PORTUGAL 2020 Partnership Agreement and also by LIACC (FCT/UID/CEC/0027/2020).

\section{Appendix A: Questionnaire applied to employers (adapted from Boustras et al., 2015)}

\section{Part A: General information:}

1. Age: years old.

2. Gender: Male $\square \quad$ Female $\square$

3. What is your schooling level? $\square$ Primary education $\left(4^{\text {th }}\right.$ year $) \quad \square$ Elementary education $\left(9^{\text {th }}\right.$ year $)$

$\square$ Secondary education $\left(12^{\text {th }}\right.$ year $) \quad \square$ Ungraduated or graduate education

4. How many years has your business been operating? years

5. What waste management activities are carried out in your firm? (can choose more than one option)

Paper, Plastics \& Textiles (SPS\&T) $\square \quad$ Scrap metals $\square \quad$ End of Life Vehicles (ELV) $\square$

Waste Electrical and Electronic Equipment (WEEE) $\square$

6. How many people operate in your firm?

\begin{tabular}{|l|l|}
\hline Number of workers & \\
\hline Number of managers and administrative support & \\
\hline
\end{tabular}

7. In the last two years, how many occupational accidents have occurred in your firm (absent from work for more than 3 days)?

\section{Part B: OHS Management Activities:}

1. The following items refers to prevention activities. Answer Yes /No considering whether they are developed or not in your firm.

\begin{tabular}{|c|c|}
\hline 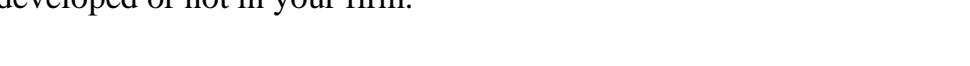 & Yes No \\
\hline My firm has an OHS policy & $\square$ \\
\hline I have set OHS goals for my firm & $\square$ \\
\hline I provide adequate Personal Protective Equipment to my employees & $\square$ \\
\hline I have an accident recording system & $\square$ \\
\hline I provide information about the risks that my workers are exposed & $\square$ \\
\hline In my firm exist a written risk assessment & $\square$ \\
\hline I provide OHS training to my employees & $\square$ \\
\hline I promote proper medical surveillance of my employees & $\square$ \\
\hline
\end{tabular}

2. If you promote OHS training, in the last year how many hours of training have you provided to your workers? hours

3. The time I spend on OSH activities is: 


\begin{tabular}{|ccccc|}
\hline Very low & Low & Medium & High & Very high \\
\hline$\square$ & $\square$ & $\square$ & $\square$ & $\square$ \\
\hline
\end{tabular}

\section{Appendix B: Safety performance aspects assessed by OHS practitioners (adapted from Boustras et al., 2015)}

1. Does the firm comply with health and safety law and regulations? ( 1 minimum to 10 maximum).

\begin{tabular}{|llllllllll|}
\hline $\mathbf{1}$ & $\mathbf{2}$ & $\mathbf{3}$ & $\mathbf{4}$ & $\mathbf{5}$ & $\mathbf{6}$ & $\mathbf{7}$ & $\mathbf{8}$ & $\mathbf{9}$ & $\mathbf{1 0}$ \\
\hline$\square$ & $\square$ & $\square$ & $\square$ & $\square$ & $\square$ & $\square$ & $\square$ & $\square$ & $\square$ \\
\hline
\end{tabular}

2. For each of the aspects, determine for each company the degree of compliance, considering the scale presented:

\begin{tabular}{|c|c|c|c|c|c|}
\hline Safety performance aspect & $\begin{array}{l}\text { Not at } \\
\text { all }\end{array}$ & $\begin{array}{l}\text { Only a } \\
\text { little }\end{array}$ & $\begin{array}{c}\text { To some } \\
\text { extent }\end{array}$ & $\begin{array}{l}\text { Rather } \\
\text { much }\end{array}$ & $\begin{array}{l}\text { Very } \\
\text { much }\end{array}$ \\
\hline $\begin{array}{l}\text { Does the firm take initiatives regarding health and } \\
\text { safety? }\end{array}$ & $\square$ & $\square$ & $\square$ & $\square$ & $\square$ \\
\hline $\begin{array}{l}\text { Does the firm provide individual safety protection } \\
\text { measures? }\end{array}$ & $\square$ & $\square$ & $\square$ & $\square$ & $\square$ \\
\hline $\begin{array}{l}\text { Does the firm provide general safety protection } \\
\text { equipment? }\end{array}$ & $\square$ & $\square$ & $\square$ & $\square$ & $\square$ \\
\hline $\begin{array}{l}\text { Does the firm operate the basic health and safety } \\
\text { systems? }\end{array}$ & $\square$ & $\square$ & $\square$ & $\square$ & $\square$ \\
\hline $\begin{array}{l}\text { Does the employer know the basic aspects of health } \\
\text { and safety law and regulations, which are relevant } \\
\text { for him? }\end{array}$ & $\square$ & $\square$ & $\square$ & $\square$ & $\square$ \\
\hline $\begin{array}{l}\text { Do employees use the provided individual safety } \\
\text { protection measures? }\end{array}$ & $\square$ & $\square$ & $\square$ & $\square$ & $\square$ \\
\hline
\end{tabular}

\section{REFERENCES}

Antonsson, A.B., Birgersdotter, L., Bornberger-dankvardt, S., 2002. Small Enterprises in Sweden - Health and Safety and the Significance of Intermediaries in Preventive Health and Safety. Stockholm, Sweden: National Institute for Working Life.

Giaccone, M., 2010. Health and safety at work in SMEs: Strategies for employee information and consultation. Eurofound.

Arquillos, A.L., Romero, J.C.R., Gibb, A., 2012. Analysis of construction accidents in Spain, 2003-2008. Journal of Safety Research, 43(5-6), 381-388. https://doi.org/10.1016/j.jsr.2012.07.005

Binion, E., Gutberlet, J., 2012. The effects of handling solid waste on the wellbeing of informal and organized recyclers: a review of the literature. International Journal of Occupational and Environmental Health, 18(1), 43-52, DOI: 10.1179/1077352512Z.0000000001

Blewett, V., O'Keeffe, V., 2011. Weighing the pig never made it heavier: auditing OHS, social auditing as verification of process in Australia. Safety Science, 49, 1014-1021. https://doi.org/10.1016/j.ssci.2010.12.010 
Bluff, E., 2019. How SMEs respond to legal requirements to provide information, training, instruction and supervision to workers about work health and safety matters. Safety Science, 116, 45-57. https://doi.org/10.1016/j.ssci.2019.02.036

Bonafede, M., Corfiati, M., Gagliardi, D., Boccuni, F., Ronchetti, M., Valenti, A., Marinaccio, A., Iavicoli, S., 2016. OHS management and employers' perception: differences by firm size in a large Italian company survey. Safety Science, 89,11-18. http://dx.doi.org/10.1016/j.ssci.2016.05.012

Bonafede, M., Corfiati, M., Gagliardi, D., Boccuni, F., Ronchetti, M., Valenti, A., Marinaccio, A., Iavicoli, S., 2016. OHS management and employers' perception: differences by firm size in a large Italian company survey. Safety Science, 89, 11-18. https://doi.org/10.1016/j.ssci.2016.05.012

Boustras, G., Hadjimanolis, A., Economides, A., Yiannaki, A., Nicolaides, L., 2015. Management of health and safety in micro-firms in Cyprus-Results from a Nationwide Survey. Safety Science, 79(1), 305-313. https://doi.org/10.1016/j.ssci.2015.06.014

Bradbury, J. C. (2006). Regulatory federalism and workplace safety: evidence from OHSA enforcement, 1981-1995. Journal of Regulatory Economics, 29(2), 211-224.

Brun, J.P., Loiselle, C.D., 2002. The roles, functions and activities of safety practitioners: the current situation in Québec. Safety Science, 40(6), 519-536. https://doi.org/10.1016/S09257535(01)00018-2

Cagno, E., Micheli, G.J.L., Jacinto, C., Mais, D., 2014. An interpretive model of occupational safety performance for Small- and Medium-sized Enterprises. International Journal of Industrial Ergonomics, 44(1), 60-74. https://doi.org/10.1016/j.ergon.2013.08.005

Cañamares, M.S., Escribano, B.M.V., García, M.N.G., Barriuso, A.R., Sáiz, A.R., 2017. Occupational risk-prevention diagnosis: A study of construction SMEs in Spain. Safety Science, 92, 104-115. https://doi.org/10.1016/j.ssci.2016.09.016

Casey, T.W., Krauss, A.D., Turner, N., 2018. The one that got away: Lessons learned from the evaluation of a safety training intervention in the Australian prawn fishing industry. Safety Science, 108, 218-224. http://dx.doi.org/10.1016/j.ssci.2017.08.002

Champoux, D., Brun, J.P., 2003. Occupational health and safety management in small size enterprises: an overview of the situation and avenues for intervention and research. Safety Science 41, 301-318. https://doi.org/10.1016/S0925-7535(02)00043-7

Colligan, M. J., \& Cohen, A. (2004). The role of training in promoting workplace safety and health. The psychology of workplace safety, 223-248.

Dianat, I., Kord, M., Yahyazade, P., Karimi, M.A., Stedmon, A.W., 2015. Association of individual and work-related risk factors with musculoskeletal symptoms among Iranian sewing machine operators. Applied Ergonomics, 51, 180-188. https://doi.org/10.1016/j.apergo.2015.04.017

Engkvist, I.L., 2010. Working conditions at recycling centres in Sweden - Physical and psychosocial work environment. Applied Ergonomics, 41(3), 347-354. https://doi.org/10.1016/j.apergo.2009.06.008

European Agency for Safety and Health at Work (EU-OSHA), 2010. Mainstreaming OHS into business management. <http://OHSa.europa.eu/en/publications/reports>

European Parliament, 2017. Towards a circular economy - Waste management in the EU. STOA - Science and Technology Options Assessment. https://doi.org/10.2861/978568

Eurostat, 2013. Waste and materials recovery statistics - NACE Rev. 2. http://ec.europa.eu/

Eurostat, 2018. Municipal waste statistics. http://ec.europa.eu/

Eurostat, 2019a. Recycling rate of municipal waste Products Datasets. https://ec.europa.eu/eurostat/web/products-datasets/product?code=sdg_11_60

Eurostat, 2019b. Waste excluding major mineral waste. https://ec.europa.eu/eurostat/web/waste/key-waste-streams/waste-excluding-mineral

Fabiano, B., Currò, F., Pastorino, R., 2004. A study of the relationship between occupational injuries and firm seize and type in the Ilatian industry. Safety Science, 42, 587-600. https://doi.org/10.1016/j.ssci.2003.09.003 
Gopang, M.A., Nebhwani, M., Khatri, A., Marri, H.B., 2017. An assessment of occupational health and safety measures and performance of SMEs: An empirical investigation. Safety Science, 93, 127-133. https://doi.org/10.1016/j.ssci.2016.11.024

Gould, J., Glossop, M., Gould, J., 2000. Review of hazard identification techniques. Sheffield, UK: Health and Safety Laboratory HSL/2005/58, Health and Safety Executive.

Grzywinski, W., Wandycz, A., Tomczak, A., Jelonek, T., 2016. The prevalence of self-reported musculoskeletal symptoms among loggers in Poland. International Journal of Industrial Ergonomics, 52, 12-17.

Hadjimanolis, A., Boustras, G., Economides, A., Yiannaki, A., Nicolaides, L., 2015. Work attitudes and safety performance in micro-firms - Results from a nationwide survey: (the opinion of the employees). Safety Science, 80, 135-143. https://doi.org/10.1016/j.ssci.2015.07.026

Hadjimanolis, A., Boustras, G. 2013. Health and safety policies and work attitudes in Cypriot companies. Safety Science, 52, 50-56. https://doi.org/10.1016/j.ssci.2012.03.012

Hasle, P., Limborg, H.J., 2006. A review of the literature on preventive occupational health and safety activities in small enterprises. Industrial Health, 44 (1), 6-12. http://doi.org/ 10.2486/indhealth.44.6

Hasle, P., Kvorning, L.V., Rasmussen, C.D.N., Smith, L.H., Flyvholm, M-A., 2012. A model for design of tailored working environment intervention programmes for small enterprises. Safety and Health at Work, 3, 181-91. https://doi.org/10.5491/SHAW.2012.3.3.181

INE, 2014. Estatísticas dos Resíduos 2014. Lisboa: Instituto Nacional de Estatística.

Is1k, I.N., Atasoylu, E. (2017). Occupational safety and health in North Cyprus: Evaluation of risk assessment. Safety Science, 94, 17-25. http://dx.doi.org/10.1016/j.ssci.2016.12.020

ISO 31010:2009. Risk management- Risk assessment techniques. International Organization for Standardization.

Jankovský, M., Allman, M., Allmanová, Z., Ferenčík, M., Merganič, J., Messingerová, V., 2019. Is timber haulage safe? A ten year study of occupational accidents. https://doi.org/10.1016/j.ssci.2018.11.018

Kontogianni, S., Moussiopoulos, N., 2017. Investigation of the occupational health and safety conditions in Hellenic solid waste management facilities and assessment of the in-situ hazard level. Safety Science, 96, 192-197. https://doi.org/10.1016/j.ssci.2017.03.025

Kuijer, P., Sluiter, J., Frings-Dresen, M., 2010. Health and safety in waste collection: towards evidence-based worker health surveillance. Am. J. Ind. Med. 53, 1040-1064.

Ma, Q., Yuan, J., 2009. Exploratory study on safety climate in Chinese manufacturing enterprises. Safety Science, 47, 1043-1046. doi:10.1016/j.ssci.2009.01.007

Ma, Q., Yuan, J., 2009. Exploratory study on safety climate in Chinese manufacturing enterprises. Safety Science, 47(7), 1043-1046. https://doi.org/10.1016/j.ssci.2009.01.007

Madsen, A.M., Frederiksen, M.W., Kurdi, I.M., Sommer, S., Flensmark, E., Tendal, K., 2019. Expanded cardboard waste sorting and occupational exposure to microbial species. Waste Management, 87, 345-356. https://doi.org/10.1016/j.wasman.2019.02.018

Masi, D., Cagno, E., 2015. Barriers to OHS interventions in Small and Medium-sized Enterprises. Safety Science, 71, 226-241. https://doi.org/10.1016/j.ssci.2014.05.020

Masi, D., Cagno, E., Micheli, G.J.L., 2014. Developing, implementing and evaluating OHS interventions in SMEs: A pilot, exploratory study. International Journal of Occupational Safety and Ergonomics, 20(3), 385-405. http:// 10.1080/10803548.2014.11077059

Micheli, G. J. L., Cagno, E., 2010. Dealing with SMEs as a whole in OHS issues: Warnings from $\begin{array}{llll}\text { empirical } & \text { evidence. }\end{array}$ https://doi.org/10.1016/j.ssci.2010.02.010

Neitzel, R.L., Crollard, A., Dominguez, C., Stover, B., Seixas, N.S., 2013. A mixed-methods evaluation of health and safety hazards at a scrap metal recycling facility. Safety Science, 51(1), 432-440. https://doi.org/10.1016/j.ssci.2012.08.012

Nordlöf, H., Wiitavaara, B., Högberg, H., Westerling, R., 2017. A cross-sectional study of factors influencing occupational health and safety management practices in companies. Safety Science, 95, 92-103. https://doi.org/https://doi.org/10.1016/j.ssci.2017.02.008 
Olsen, K., Harris, L.-A., Laird, I., Legg, S., Perry, M., Hasle, P., 2010. Differential intervention strategies to improve the management of hazardous chemicals in small enterprises. Policy and Practice in Health and Safety 8, 57-76. https://doi.org/10.1080/14774003.2010.11667748

Olsen, K. B., \& Hasle, P. (2015). The role of intermediaries in delivering an occupational health and safety programme designed for small businesses-A case study of an insurance incentive programme in the agriculture sector. Safety science, 71, 242-252.

Parejo-Moscoso, J.M., Rubio-Romero, J.C., Pérez-Canto, S., Soriano-Serrano, M., 2013. Health and safety management in olive oil mills in Spain. Safety Science 51,101-108. http://dx.doi.org/10.1016/j.ssci.2012.06.015

Pietilä, J., Räsänen, T., Reiman, A., Ratilainen, H., Helander, E., 2018. Characteristics and determinants of recurrent occupational accidents. Safety Science, 108, 269-277. https://doi.org/10.1016/j.ssci.2017.12.020

Poole, C.J.M., Basu, S., 2017. Systematic Review: Occupational illness in the waste and recycling sector. Occupational Medicine, 67, 626-636. doi:10.1093/occmed/kqx153

Probst, T.M., Graso, M., 2011. Reporting and investigating accidents: Recognizing the tip of the iceberg. In S. Clarke, C. Cooper, R. Burke (Eds.). Occupational Health and Safety. ${ }^{\text {st }}$ Edition. London: Taylor \& Francis Group

Reinhold, K., Järvis, M., Tint, P., 2015. Practical tool and procedure for workplace risk assessment: Evidence from SMEs in Estonia. Safety Science, 71, 282-291. https://doi.org/10.1016/j.ssci.2014.09.016

Robson LS, National Institute for Occupational Safety and Health. Dept. of Health and Human Services. Guide to evaluating the effectiveness of strategies for preventing work injuries: how to show whether a safety intervention really works. : Department of Health and Human Services, Centers for Disease Control and Prevention, National Institute of Occupational Safety and Health; 2001.

Rodrigues, M.A., Arezes, P., Leão, C.P., 2017. Risk assessment: getting the 'big picture'. In Boustras, G., Guldenmund, F. (Eds). Handbook of Safety Management in SME's. Chapter 2. London: Taylor \& Francis Group.

Barbosa, C., Azevedo, R., Rodrigues, M.A. (2019). Occupational safety and health performance indicators in SMEs: a literature review. Work: A Journal of Prevention, Assessment and Rehabilitation 64(2), 217-227. http://10.3233/WOR-192988

Searl, A., Crawford, J., 2012. Review of Health Risks for Workers in the Waste and Recycling Industry. Research Report 2012. Institute of Occupational and Environmental Medicine. https://www.bohrf.org.uk/downloads/Review of Health Risks for workers in the Waste and_Recycling_Industry.pdf

Seneviratne, M., Phoon, W.O., 2006. Exposure Assessment in SMEs: A Low-Cost Approach to Bring OHS Services to Small-Scale Enterprises. Industrial Health, 44(1), 27-30. https://doi.org/10.2486/indhealth.44.27

Shi, X. (2009). Have government regulations improved workplace safety?: a test of the asynchronous regulatory effects in China's coal industry, 1995-2006. Journal of safety research, 40(3), 207-213.

Sørensen, O.H., Hasle, P., Bach, E., 2007. Working in small enterprises - Is there a special risk? Safety Science 45, 1044-1059. https://doi.org/10.1016/j.ssci.2006.09.005

Tappura, S., Sievänen, M., Heikkilä, J., Jussila, A., Nenonen, N., 2015. A management accounting perspective on safety. Safe. Sci. 71, 151-159

Zolnikov, T.R., Silva, R.C., Tuesta, A.A., Marques, C.P., Cruvinel, V.R.N., 2018. Ineffective waste site closures in Brazil: A systematic review on continuing health conditions and occupational hazards of waste collectors. Waste Management, 80, 26-39. https://doi.org/10.1016/j.wasman.2018.08.047

Zwetsloot, G.I.J.M., 2014. OHS management in small and micro enterprises. https://OHSwiki.eu/wiki/OHS_management_in_small_and_micro_enterprises 
Table 1: some examples of OHS management practices (adapted from Brun and Loiselle, 2002)

\begin{tabular}{l|l|l|l} 
& $\begin{array}{l}\text { Organizational } \\
\text { dimension }\end{array}$ & Technical dimension & Human dimension \\
\hline Strategic & Develop OHS policy & $\begin{array}{l}\text { Influence strategic } \\
\text { technical decisions }\end{array}$ & $\begin{array}{l}\text { Foster OHS among top } \\
\text { management }\end{array}$ \\
\cline { 2 - 4 } & Develop OHS budget & $\begin{array}{l}\text { Develop standards for } \\
\text { the use of machines }\end{array}$ & $\begin{array}{l}\text { Foster OHS among } \\
\text { workers }\end{array}$ \\
\cline { 2 - 4 } & $\begin{array}{l}\text { Evaluate annual OHS } \\
\text { performance }\end{array}$ & $\begin{array}{l}\text { Provide safety related } \\
\text { advices }\end{array}$ & $\begin{array}{l}\text { Involve foremen in } \\
\text { OHS changes }\end{array}$ \\
\hline Operational & $\begin{array}{l}\text { Apply policy and } \\
\text { procedures }\end{array}$ & $\begin{array}{l}\text { Conduct studies into } \\
\text { technical safety } \\
\text { problems }\end{array}$ & Inform workers \\
\cline { 2 - 4 } & Carry out paperwork & Identify hazards & Train workers \\
\cline { 2 - 4 } Investigate accidents & Assess the risk & $\begin{array}{l}\text { Meet with workers to } \\
\text { discuss OHS }\end{array}$ \\
& & &
\end{tabular}


Table 2: Summary of organizational variables, OHS preventive activities and performance level

\begin{tabular}{|c|c|}
\hline Variable & Information \\
\hline \multicolumn{2}{|l|}{ Size of firm } \\
\hline Micro-sized $(N)$ & 55 \\
\hline Small-sized $(N)$ & 12 \\
\hline \multicolumn{2}{|l|}{ Age of enterprise } \\
\hline Average $\pm s d(\min -\max )$ & $14.51 \pm 11.31(1-54)$ \\
\hline \multicolumn{2}{|l|}{ No. employees } \\
\hline Micro-sized: Average \pm sd (min-max) & $3.89 \pm 2.19(1-9)$ \\
\hline Small-sized: Average $\pm s d$ (min-max) & $14.78 \pm 5.49(11-29)$ \\
\hline \multicolumn{2}{|l|}{ Employees' gender } \\
\hline Female (\%) & 22.5 \\
\hline Male (\%) & 77.5 \\
\hline \multicolumn{2}{|l|}{ Protective and preventive services } \\
\hline Yes $(\%)$ & 89.2 \\
\hline No $(\%)$ & 10.8 \\
\hline \multicolumn{2}{|l|}{ Years with OHS preventive activities } \\
\hline Average $\pm s d(\min -\max )$ & $3.92 \pm 3.7(0-16)$ \\
\hline \multicolumn{2}{|c|}{ Number of visits by OHS external services in the last two years } \\
\hline No visit (\%) & 30.5 \\
\hline One visit (\%) & 28.8 \\
\hline Two visits (\%) & 5.1 \\
\hline Three visits (\%) & 35.6 \\
\hline \multicolumn{2}{|l|}{ Amount of time spent by employer in OHS activities } \\
\hline Very low (\%) & 40.0 \\
\hline Low $(\%)$ & 25.3 \\
\hline Moderate (\%) & 30.7 \\
\hline $\operatorname{High}(\%)$ & 2.7 \\
\hline Very high (\%) & 1.3 \\
\hline OHS training (hours/year): Average $\pm s d$ (min-max) & $1.46 \pm 4.98(0-15)$ \\
\hline \multicolumn{2}{|l|}{ Injury frequency rate } \\
\hline Average $\pm s d(\min -\max )$ & $80.03 \pm 93.32(0-500)$ \\
\hline \multicolumn{2}{|l|}{ OHS performance level } \\
\hline Average \pm sd (min-max) & $31.01 \pm 5.00(17-38)$ \\
\hline \multicolumn{2}{|l|}{ Total Sample } \\
\hline Enterprises $(N)$ & 66 \\
\hline Employees $(N)$ & 361 \\
\hline Employers $(N)$ & 66 \\
\hline
\end{tabular}


Table 3: Summary of OHS management activities conducted at the enterprises

\begin{tabular}{lcc}
\hline Variable & Yes & No \\
\hline Existence of an OHS policy (\%) & 42.5 & 57.5 \\
Existence of OHS objectives (\%) & 40.3 & 59.7 \\
Provision of PPE (\%) & 97.3 & 2.7 \\
Existence of accident recording mechanism (\%) & 69.9 & 30.1 \\
Existence of a written risk assessment (\%) & 89.2 & 10.8 \\
Informing employees of about OHS risks (\%) & 91.9 & 8.1 \\
Provision of health surveillance (\%) & 97.3 & 2.7 \\
OHS training (\%) & 68.9 & 31.1 \\
\hline
\end{tabular}


Table 4: Spearman correlations between main variables

\begin{tabular}{llllll}
\hline Variable & $\mathbf{1}$ & $\mathbf{2}$ & $\mathbf{3}$ & $\mathbf{4}$ & $\mathbf{5}$ \\
\hline (1) OHS performance & & & & & \\
(2) OHS objectives/policy & $0.399^{* *}$ & & & & \\
(3) Compliance with legal requirements for OHS & $0.513^{* *}$ & $0.446^{* *}$ & & & \\
(4) Time dedicated by employer to OHS issues & $0.411^{* *}$ & $0.349^{* *}$ & $0.434^{* *}$ & & \\
(5) OHS training (hours) & $0.337^{* *}$ & 0.156 & $0.475^{* *}$ & $0.313^{*}$ & \\
(6) Number of visits by external advisory & $0.298^{*}$ & -0.166 & $0.276^{*}$ & 0.122 & 0.029 \\
services & & & & & \\
\hline
\end{tabular}

Note: $* * \mathrm{p}<0.01 ;{ }^{*} \mathrm{p}<0.05$ 
Table 5: Results of multiple regression analyses for variables predicting OHS performance. The model coefficients are represented by $\beta$, the tStudent statistic by $t$ and $\mathrm{p}$ represent the statistical significance of the test.

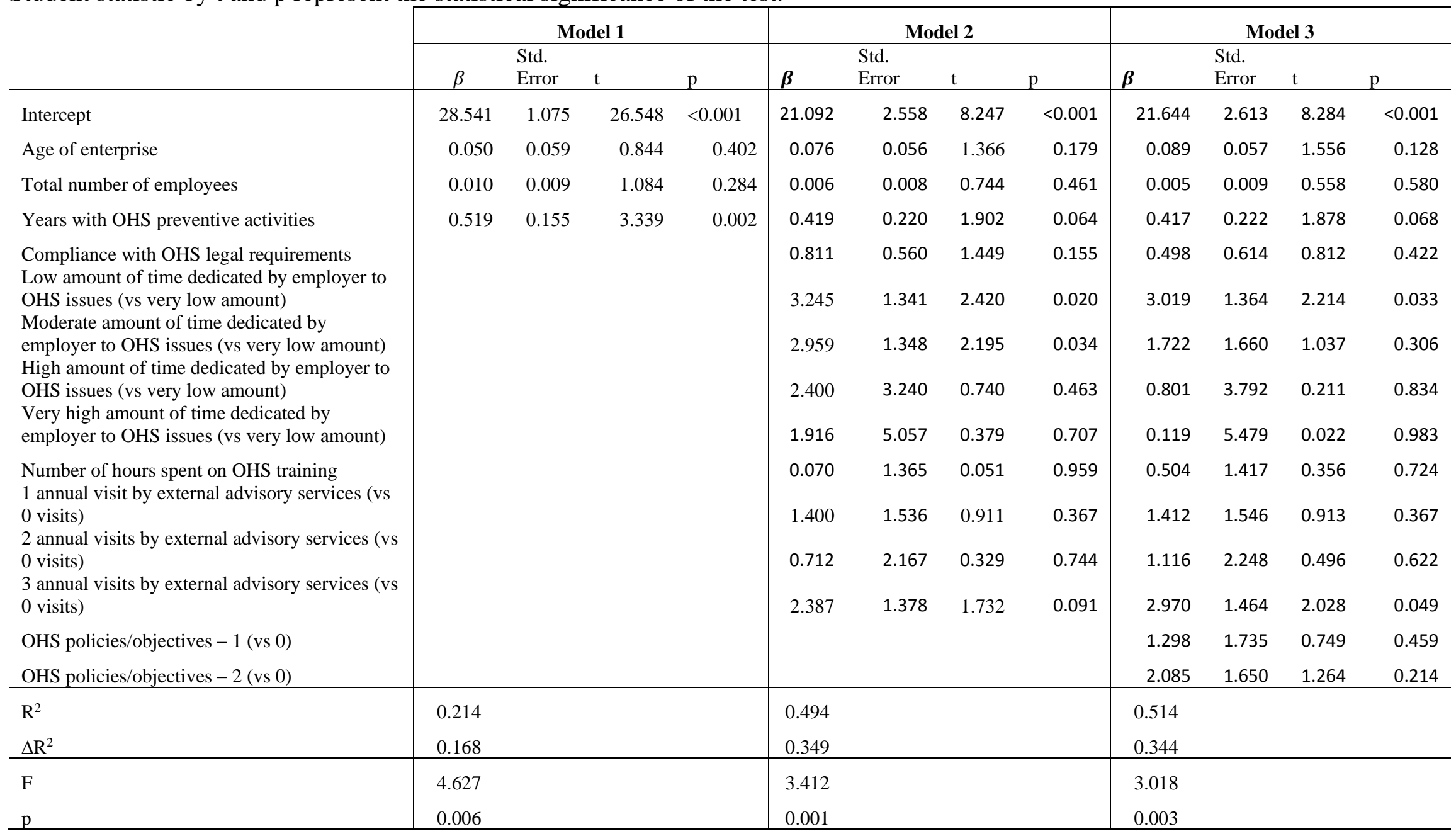


